\title{
Naming Culinary in Mandailing Society: A Culinary Linguistic Approach
}

\author{
Rahmawati $^{1}$, Mulyadi ${ }^{*}$ \\ ${ }^{1}$ Universitas Sumatera Utara, Indonesia \\ ${ }^{2 *}$ Corresponding Author: Universitas Sumatera Utara, Indonesia \\ rahmawati165@gmail.com,mulyadi@usu.ac.id
}

\begin{abstract}
This study examines culinary naming in the mandailing community. This study aims to see what culinary names exist in the Mandailing community according to the theory used. This research involves a concept or meaning, a word or symbol and something that is referred to as the relation between the elements described in the 'meaning triangle' pioneered by Ogden and Richard. This research is expected to be a reference for the Mandailing community to find out the meaning and type of culinary with a qualitative descriptive method. Data collection techniques using Spradley's ethnographic model using interviews and participant observation methods. The results showed that there were 8 culinary names for the mandailing community.
\end{abstract}

Keywords naming; culinary; Mandailing society

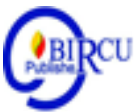

\section{Introduction}

Regional cuisine is a distinctive identity that differentiates it from other regions. These differences, for example, can be seen from the type of food, processing, presentation and taste. Food or culinary is also a basic human need which is created from the ability of human creations. Unlike other creatures on this earth, humans are able to seek, select and obtain and process food. Only humans are able to spice up the culinary variety of their food and create them in such a way as to produce distinctive foods to meet the body's needs and are beneficial for health (Gerhardt, 2013). So, it can be said that in the activity of cooking food or the process of preparing a culinary delights, it shows the human ability to transform nature. Globally, consumers account for $30.9 \%$ of all the food wasted (Srinivas in Huho, 2020).

Food is a bridge between nature and culture" (Fischler 1988 in Gerhardt, 2013). Indonesian forests have great potential in contributing to the provision of food for the Community (Komarayanti, 2018). That is, the human ability to think creatively is a form of culture. Wierzbicka (1997: 1) also reminded that if there is a very close relationship between social life and lexicons in the language of the speakers, these cultural activities produce more than one vocabulary or lexicon for one activity. The same is the case with culinary processing, serving and naming activities.

The term culinary is not new to talk about, because culinary is very busy being discussed in all electronic media and social media. The term culinary tourism is becoming a trend, because besides eating, people can also travel and can fulfill their desire for selfactualization on social media by uploading photos of their culinary tours on personal social media. Thus, it is undeniable that in the end culinary delights become one of the mainstays of regional tourism in Indonesia. 
A number of studies that have been carried out regarding food and language have been carried out in several languages in the world, such as vocabulary (related to cooking Lehrer, 1972), eating and drinking verbs (Newman, 2009), eating in Mandarin (Zhengdao, 2010), taste and spices cuisine in Southeast Asia (Enfield, 2011), the relationship between language and reason (Majid \& Levinson, 2011)), Persian metaphors (Khajeh \& Ho Abdullah, 2012), food naming (Kusmaningtyas, et al., 2013), the role of food in workplace discourse (Holmes, et al., 2013), food metaphors (López, 2014), Boholano's culinary linguistics about food and Filipino language (Jabonillo, 2016). Dohra Fitrisia in her dissertation which examines Traditional Culinary in Aceh Language: Culinary Linguistic Studies (2019).

One of the areas that have a culinary wealth is Mandailing. The Mandailing community has a variety of delicious and healthy culinary delights with unique processing methods. However, the culinary richness of the Mandailing community, some of the people already know but some are still not familiar with the typical Mandailing food. Therefore, researchers are interested in introducing the culinary delights of the Mandailing community, especially in this study, through the culinary names of the Mandailing community.

\section{Review of Literatures}

Name is a word to refer to or call people, places, goods, animals, and so on (Bandana, 2015: 2; Sibarani, 1993: 8). Name is also a coded word, because it can be transformed and name is also a free creation by someone who gives it (Lévi-Strauss in Bruck and Bodenhorn, 2006: 9-10). A name for something is an agreed convention, for example the British say 'egg' while Cantonese Chinese say 'daan' and Italy 'vovo', but if there is a change to the contrary, it will be fine as long as everyone agrees (Jurafsky, 2014: 159).

Then, the function of names in language activities is to separate reality for humans, to distinguish an object from another object and also a person from another (Sibarani, 1993: 21). The naming process is related to the reference. The naming is conventional, that is, based on the habits of the people who wear it, and is arbitrary, that is, based on the will of the community. For example, the house lexeme refers to objects that have roofs, walls, doors, windows, and are commonly used by humans for resting or in the context of food, for example, fried bananas refer to solid foods made from bananas, the processing process is fried in oil.

The naming process is actually human cultivation to make it easier for them to communicate as an activity to replace objects, a process of activity symptoms and properties (Pateda, 2010: 276). Almost every name that already exists reflects a culture, for example, the name itself reflects the culture that is owned by that self. Knowledge of names is commonly called onomastic (Sibarani, 1993: 8; Crystal, 2008: 339). This science is divided into two branches, namely first, anthroponym, which is knowledge that studies the history or origin of the name of a person or that which is copied; second, toponymy, namely knowledge that studies the history or origin of place names. The term anthroponym comes from the Greek word anthropos 'male' or 'human' (Koopman 2002: 10 in Makondo 2009) and this refers to a person's name (personal names). According to Danesi (2004: 118) onomastics comes from the Greek, namely "name" onoma. So Anthroponomastics is about knowledge that learns about people's names, while onomastics is about knowledge of names in general (Collins Cobuild 1987). Onomastics 
or onomatology is a branch of linguistics that studies the structure, semantics, pragmatics and etymology of names (Crystal 1992 in Makondo 2009).

So, naming is the process of looking for language symbols to describe objects, concepts, processes, and so on, by utilizing existing vocabulary; among others, the possible changes in meaning or the creation of words or groups of words (Kridalaksana, 1982: 124). The naming of objects, may be based on the characteristics and characteristics that stand out from the object, for example physical or non-physical characteristics; or it may also refer to positive hopes that its citizens have the efforts and mentality that go together and are in line with the meaning behind the name. However, in general the "naming" contains philosophical and symbolic elements that are full of meaning. Nida (1979: 64) states that the naming process is related to the reference. The process is related to the reference.

Furthermore, naming is one of the four ways in analyzing meaning or meaning components, the other three ways are paraphrasing, defining, and classifying (Nida, 1979: 64). There are ten ways of naming according to Sudaryat (2006), namely (1) sound imitation (onomatopoeia), (2) mention of parts (sinecdoche), (3) mention of distinctive characteristics, (4) mention of apelativa, (5) mention of places, (6) ) mention of materials, (7) mention of similarity, (8) shortening (abbreviation), (9) new names, (10) terminology. In the context of culinary linguistics, the name of a food item or dish can make someone's mouth drool, literally (Jabonillo, 2016: 22). Furthermore, Jabonillo (2016) also added that naming food or onomastic food is a simple concept, namely you make food, you name it whatever.

\section{Research Methods}

The approach used in this research is a qualitative approach with ethnographic methods. The ethnographic method in this research is the Spradley analysis model, also known as the ethnographic analysis model, which is to learn language by collecting data directly in the field from native speakers, including their culture which is then analyzed systematically.

The main purpose of this activity according to Spradley (1979: 3) is to understand a view of life from the point of view of the indigenous people by describing their culture. The technique of collecting data from Spradley's (1979) ethnographic model used interviews and participant observation. Data collection uses two types of methods, namely.

The first step is collecting data from several sources, namely primary and secondary data sources, and then followed by observation, questionnaires, interviews, tests, and documentation. While the Data Collection Instrument is a tool usd to collect data. After the data collection procedure was carried out, the researcher then conducted data grouping. Data grouping serves to make it easier for researchers to analyze existing data to make it more practical. Then came the data analysis stage. The final step of the research method is to present the results obtained in the discussion.

\section{Discussion}

The theory used in culinary naming in mandailing society: the culinary linguistic approach is Ogden and Richard's (1946) naming involves a concept or meaning, a word or symbol/symbol and something that is referred to as the relation between these elements is described in a 'meaning triangle'. As shown below: 
Budapest International Research and Critics in Linguistics and Education (BirLE) Journal Volume 4, No 1, January 2021, Page: 486-493 e-ISSN: 2655-1470 (Online), p-ISSN: 2655-2647(Print) www.bircu-journal.com/index.php/birle email: birle.journal@gmail.com

Figure 1. Meaning Triangle 


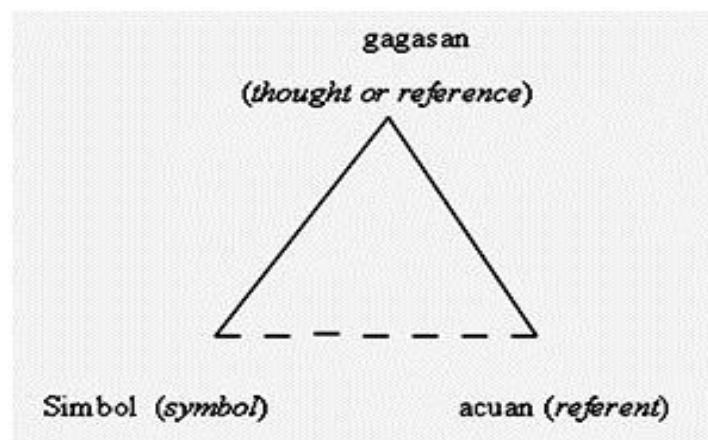

Figure 1. Meaning Triangle

The types of naming that have been found in Mandailing culinary names are based on color, main ingredients, processing/manufacturing methods, similarity in shape, taste, seasoning, and cooking utensils. The explanation of the 8 types of culinary naming is as follows:

\subsection{Naming by Color}

This naming is based on the color that appears in a number of culinary preparations. The color in question is the pattern or impression the eye gets when viewing the culinary. An example of Mandailing culinary, which is named after its color, is ikan digule rata. In the processing process using cayenne pepper, red chilies, turmeric, shallots, galangal, lemongrass, turmeric leaves, then given a little coconut milk, and the type of fish is gold fish. Then it is cooked and produces a yellow-green color.

\subsection{Naming Based on the Main Material}

Naming based on the main ingredient is the naming based on the name of the main ingredient used in the manufacture / processing of vegetable-derived culinary is Bolu salak kenanga. The main ingredient is salak fruit. This is characteristic of sidempuan now because it only exists in Padang Sidempuan. The main ingredients are Salak fruit, flour, developer, sugar, butter. Another example of naming Sambal Kantori Joruk. This Sambal is a unique mandailing food. This Sambal Kantori Joruk is a chili sauce whose main ingredients are teri and durian. The way to cook this food is the same as how to cook sambal teri in general, the difference here is that the fermented durian fruit is added.

\subsection{Naming Based on Manufacturing/Processing Method}

Culinary based on the method of manufacture is the naming given based on the method or processing process. In Mandailing, holding celebrations such as weddings, always providing food or culinary delights called gule sibodak, which means gule nangka. The culinary naming refers to the ingredients of chilies, shallots, turmeric, garlic, ombuombu, and jackfruit (sibodak). Another example is gule sambal pati, which means gule using ground coconut (pati = kelapa). It says chili sauce because there are lots of chilies. The ingredients are ground coconut, kecepe shrimp, potatoes, chilies, shallots, garlic and turmeric.

Another culinary example based on how it is made is itak poul-poul. The name of this typical Mandailing snack refers to the way it is made by hand, by clenching it, not using a cookie cutter as usual. So, the meaning of the confectionery / cake in a fist is not a snack / cake that is in the fist, but itak poul poul is the name of a typical Mandailing snack. Apart from having a distinctive shape, resembling the fingers of an adult's fist, the peculiarities of this snack also lie in the historical and philosophical values contained 
therein. In the tradition of the Mandailing people, this snack will always be presented at moments that are considered important by the community. Like when entertaining guests who come in friendship, when carrying out the rites entering a new house, At the time of the birth of the child, also at the time of the traditional wedding ceremony, this snack will be one of the gifts / gifts that must be carried by the groom's family during mangalap boru (picking up the bride). An example of culinary naming based on processing method is Bulung gadung which means cassava leaves. the method of processing is ground cassava leaves until smooth with spices such as onions, turmeric, ginger and others. Furthermore, coconut milk is added. The taste is guaranteed to be delicious and addicting. the method of processing is ground cassava leaves until smooth with spices such as onions, turmeric, ginger and others. Furthermore, coconut milk is added. The taste is guaranteed to be delicious and addicting. the method of processing is ground cassava leaves until smooth with spices such as onions, turmeric, ginger and others. Furthermore, coconut milk is added. The taste is guaranteed to be delicious and addicting.

\subsection{Naming Based on Similarity of Form}

Culinary names are based on the similarity of culinary forms to other objects or parable of properties/textures of objects found in culinary names. Mandailing culinary name based on similar shape is kue talam made from flour and cassava. This snack is made in the tray after cooking. This snack is usually found at traditional wedding ceremonies or welcoming guests and celebrating major holidays.

\subsection{Naming Based on Taste}

Culinary names are also given based on the taste of the food that is felt. An example of mandailing food or culinary Ikan mas holat is a food that is very much in demand by visitors everywhere because this food menu has very unique characteristics. This Ikan mas holat is a food menu that uses grilled goldfish and holat sauce. This cooking secret spice is made from spices from the stew of young rattan shoots so that there is a bitter taste in the sauce, but don't worry, the resulting bitter taste will not make you stop eating, but it can actually increase your appetite which can make you addicted to tasting it continuously.

This menu will be more delicious if there is orange juice on top which can produce a savory and fresh taste. Another example in mandailing culinary is Pakkat or pucuk rotan. Even this food is processed very easily. Just burn it and eat it with raw chili sauce. The bitter and thick taste of pucuk rotan is what makes connoisseurs addicted to continue eating it.

\subsection{Naming Based on Spices}

The spice-based naming is the material used in culinary manufacturing of types of plants with a distinctive smell that are used to give food flavor, such as ginger, shallot, garlic, turmeric, red chilies, coriander and typical Mandailing andaliman spices, tamarind, flowers. kecombrang, and lokio (daun bawang batak). An example of the names of typical Mandailing foods based on seasoning is Gule Asam Pode. The method of making gulai asam pode turns out to be slightly different from the usual method of making curry This dish is sufficient to use water and ingredients such as water, salt, lemongrass, galangal, turmeric leaves, turmeric, lime, red chilies, bay leaves and a little ginger. Do not forget to add slices of red and white onions. The spices that have been mashed are then sauteed and poured with water. Then put the fish meat, then cooked until the fish is cooked and the sauce thickens and absorbs. Another example of naming given based on seasoning is Gule Ikan Salai. Its savory and spicy taste makes this curry a mainstay in a number of typical 
Mandailing restaurants. Smoked fish itself is a fish that is preserved by smoking. The method of preserving food by drying and salting has been known since at least the Neolithic era. The taste of smoked fish curry is more distinctive because of the smoked aroma of the fish. How to make it is also quite easy because the spices are easy to get. With the seasoning of 3 sale fish, soak in hot water for 5 minutes, remove and drain, 3 pieces of lime leaves, $1 / 2$ coconut, made of coconut milk, enough powdered sugar, sufficient fine salt, 2 potatoes, peeled and clean, cut split. Apart from potatoes, some also cook it with cassava or eggplant leaves, 2 shallots, sliced, 1 lemongrass / lemongrass, 2 slices of ginger, 3 red chilies, two knuckles of turmeric, pepper. Another example of naming given based on the spices used in the cooking is Ikan arsik. This culinary refers to the elements of various spices and special ingredients such as andaliman, tamarind patikala, kecombrang flowers, and lokio (daun bawang batak).

\subsection{Naming Based on Cookware}

Naming based on cooking utensils is a naming based on the name of the cookware used when processing the food. The name of this food in Mandailing culinary is Alame. Alame is a typical Mandailing lunkhead wrapped in woven pandanus leaves. The composition is brown sugar, glutinous rice flour and coconut milk. Alame is cooked by using a very large cauldron made of steel, to get perfect results and using firewood. The cooking process of Alame is always done together / cooperatively. This is what causes Alame to be cooked in large quantities because it will be distributed to all villagers. Alame is food that must be served during Eid and thanksgiving for the rice harvest. Until now, the tradition which involved many residents was still preserved.

\subsection{Naming Based on a Typical Philosophy}

Culinary naming based on a distinctive philosophy is a naming based on a philosophy that has long been important to the Mandailing people. The name of this food in Mandailing culinary is Sasagun. Sasagun has a distinctive philosophy, both in terms of materials and values inherent in it. When viewed from the ingredients of its manufacture, Sasagun is made from rice flour, grated coconut, brown sugar, and salt. White rice flour has the meaning of a clean heart that will strengthen kinship in the Mandailing family. Coconut, with its many functions, means that everyone must give good to his relatives. The brown sugar is sweet and sticky, meaning that everyone should give a good impression to their relatives. As for salt, as well as things that often become obstacles in a kinship. Even though there are obstacles, but like salt, even a little, it can make family relationships more "tasty". Sasagun also has a philosophical value when viewed from its physical form. Just as the Sasagun form seems to be formed from small clumps that come together to form a new flavor, so too is it that each family that is far apart, still forms a complete sense of relative even though it is blocked by distance. This is how Sasagun has had an important meaning for the Mandailing people for a long time. The method of processing Sasasagun is rice that is pounded then roasted. Sasagun is usually eaten as a substitute for rice which is ready to eat at any time and under any circumstances. The way to serve it is very simple, You just have to mix it with sugar or salt, depending on your taste. Usually only a few tablespoons, the stomach feels full and powerful. From a cultural perspective, Sasagun also has many metaphors. In the procession of "mangulangi and the harvest season is over", for example, Sasagun is brought as a gift when visiting family who is far from his village. 


\section{Conclusion}

Eight types of Mandailing culinary names were found, consisting of names based on (1) color, (2) main ingredients, (3) processing / manufacturing methods, (4) similarity in shape, (5) taste, (6) spices, (7) tools. cooking, and (8) a distinctive philosophy. Naming based on the method of manufacture / processing, and naming based on spices are found more in the types of naming culinary names compared to other culinary names.

\section{References}

Bandana, I Gde W.S. 2015. Sistem Nama Orang Bali: Kajian Struktur dan Makna. Jurnal Aksara, 27 (1) 2015, 1-11.

Bruck, G.V.\& Bodenhorn, B. 2006. The Anthropology of Names and Naming. New York: Cambridge University Press.

Crystal, D. 2008. Dictionary of Linguistics and Phonetics. Oxford: Blackwell Publishing.

Danesi, M., 2004. Messages, Signs, and Meanings: A Basic Texbook in Semiotics and Communication Theory,3rd Edition. Toronto: Canadian Scholar' Press Inc.

Dohra Fitrisia dalam disertasinya yang mengkaji Kuliner Tradisional Dalam Bahasa Aceh: Kajian Linguistik Kuliner (2019).

Enfield, NJ 2011. Taste in Two Tongues: A Southeast Asian Study of Semantic Convergence. The Senses and Society 6 (1) pp. 30-37.

Gerhardt, C, Frobenius, M, Ley, S. 2013. Culinary Linguistics; The chef's special. Amsterdam. John Benjamins Publishing Company.

Goode, J. 1992. Food. In Richard Bauman (Ed.), Folklore, Cultural Performances, and Popular Entertainments: A communication-centered handbook (pp. 233-245). New York: Oxford University Press.

Holmes, J., Marra, M. \& King, BW 2013. How Permiable is the Formal-informal Boundary at Work ?. In Gerhardt, C et al (ed), Culinary Linguistics; The chef's special (pp. 191-209) Amsterdam. John Benjamins Publishing Company.

Huho, J., Kosonei, R.C., and Musyimi, P.K. (2020). Sociodemographic Determinants of Households' Food Waste in Garissa Sub County, Kenya. Budapest International Research and Critics Institute-Journal (BIRCI-Journal) Vol 3 (2): 932-946.

Jabonillo, JP 2016. A Preliminary Research on Boholano Culinary Linguistics. (Thesis) Department of Linguistics, University of the Philippines.

Jurafsky, D. 2014. The Language of Food: A Linguist Reads the Menu. New York: W.W Norton\&Company.

Khajeh, Z \& Ho-Abdullah, I. 2012. Persian Culinary Metaphors: A cross-cultural Conceptualization. GEMA Online TM Journal of Language Studies, 12 (1) 2012, 69-87.

Komarayanti, S., Suharso, W., and Herrianto, E. (2018). Business of Local Fruit and Vegetables in Jember District as a Support of Food Security, Indonesia. Budapest International Research and Critics Institute-Journal (BIRCI-Journal) Vol I (3): 208224.

Kridalaksana, H. 1982. Kamus Linguistik. Jakarta: PT.Gramedia

Lehrer, A. 1972. Cooking Vocabularies and the Culinary Triangle of Levi-Strauss. Anthropological Linguistics (14) 5, 155-171.

López-Rodríguez, Irene. 2014. Are We What We Eat? Food Metaphors in The Conceptualization of Ethnic Group. Online linguistics 69, 7/14 http://dx.doi.org/10.13092/lo.69.1655. 
Majid, S. \& Levinson, SC 2011. The Senses in Language and Culture. The Senses and Society 6 (1) pp. 5--18.

Newman, J. 1997. Eating and Drinking as Sources of Metaphors in English. Cuadernos de Filologia Inglesa, 6/2. Pp. 213-231.

Nida, E.A. 1979. Componential Analysis of Meaning. The Hague-Paris: Mouton publishers.

Ogden, CK \& Richards, IA 1946. The Meaning of Meaning (8thedition). New York: Harcourt, Brace \& World, Inc.

Pateda, M. 2010. Semantik Leksikal. Jakarta: Rineka Cipta.

Sibarani, R. 1993. Pemberian Nama Sebagai Awal Pemunculan Linguistik. Makna Dalam Bahasa Nusantara. Robert Sibarani\&Henry Guntur Tarigan (Eds). 7-28. Bandung: Bumi Siliwangi.

Spradley, JP 1979. The Ethnographic Interview. Orlando: Rinehart and Winston, Inc.

Sudaryat, Y. 2006. Makna dalam Wacana. Bandung: CV. Yarma Widya

Wierzbicka, A. 1997. Understanding Cultures through Their Key Words. New York. Oxford University Press.

Ye. Zhengdao. 2010. Eating and Drinking in Mandarin and Shanghainese: A LexicalConceptual Analysis. In W. Christensen, E. Schier, and J. Sutton (Eds.), Proceedings of the 9th Conference of the Australasian Society for Cognitive Science (pp. 375383). Sydney. 